\title{
The role of Notch, Hh and Wnt in lung cancer development
}

\author{
El papel de Notch, Hh y Wnt en el desarrollo del cáncer de pulmón
}

\section{- Andrés Felipe Cardona', Noemí Reguart²}

'Clinical and Translational Oncology Group, Institute of Oncology, Fundación Santa Fe de Bogotá (Bogotá, Colombia).

${ }^{2}$ Foundation for Clinical and Applied Cancer Research (FICMAC) (Bogotá, Colombia).

${ }^{3}$ Medical Oncology Service, Hospital Clinic (Barcelona, Spain).

\begin{abstract}
Resumen
Hedgehog (Hh), Notch y Wingless-Int-(Wnt) son vías de señalización altamente conservadas entre las especies, esenciales para el desarrollo embrionario y para definir el destino de las células progenitoras. Todas participan en el desarrollo del pulmón, así como en diversos procesos relacionados con la reparación del epitelio en la vía aérea. La activación aberrante de estas vías se observa en una gran variedad de neoplasias, lo que sugiere que contribuyen en la evolución y el mantenimiento de un fenotipo maligno. Nueva evidencia implica la transformación maligna del linaje neuroendocrino con la activación anormal de la vía Hedgehog, mientras que la señalización de Notch y Wnt puede ser importantes en otros tipos de células tumorales derivadas de las vías respiratorias. Teniendo en cuenta la importancia de las teorías sobre la formación de tumores partir de células pluripotenciales en lugar del modelo estocástico de la carcinogénesis, no sorprende el creciente interés en estos genes que están directamente implicados en el proceso de renovación de las células troncales. En la actualidad, se están diseñando múltiples compuestos centrados en la reorientación de estas vías en el cáncer de pulmón. Esta revisión se concentra en el papel del Hh, Wnt y Notch en la tumorigénesis del cáncer de pulmón.
\end{abstract}

Palabras clave: cáncer de pulmón, Hedgehog (Hh), Notch, Wingless-Int (Wnt), celulas pluripotenciales, mofogénesis pulmonar, desarrollo.

\begin{abstract}
Hedgehog $(\mathrm{Hh})$, Notch and Wingless-Int (Wnt) are signalling pathways highly conserved among species, essential for embryonic development and progenitor cell fates. All three of these pathways participate in lung development as well as airway epithelial repair process. But interestingly aberrant activation of these pathways is observed in a large variety of cancers, suggesting its potential contribution in the evolution and maintenance of a malignant phenotype. New evidence implicates malignant transformation of the neuroendocrine lineage with aberrant Hedgehog pathway activation, whereas Notch and Wnt signalling may be important in other airway cell types. Bearing in mind the importance of the new theory of tumor formation based on stem-cells rather than on the stochastic model of carcinogenesis, it is not surprising that there has been increasing interest in these genes directly implicated in the stem-cell renewal process. Currently drug design strategies are focus on targeting these signalling pathways and may provide therapeutic opportunities in lung cancer. This review focuses on Hh, Notch Wnt signalling pathways and gives more insight about its role in lung tumorigenesis.
\end{abstract}

Key words: lung cancer, Hedgehog (Hh), Notch, Wingless-Int (Wnt), stem cells, lung morphogenesis, development.

\section{Introduction}

Lung cancer represents the leading cause of cancer mortality worldwide'. Over last decade there have been advances in the diagnostics, chemotherapy, surgery and identification of molecular patterns specific for each tumor subtype, however overall survival in lung cancer patients continues to be dismal. At present we have more data about tumorigenesis and how it is determined by dysregulation of cellular functions that control the growth by affecting cell proliferation, apoptosis, invasion and angiogenesis. Consequently genetics are at the cutting age of research into lung cancer and more target therapies are being design according to tumor molecular profiles.

Sonic hedgehog (SHh), Notch and Wingless-Int (Wnt) are highly conserved signaling pathways that have been widely studied due to its crucial function 
during embryogenesis and tissue regeneration. They are implicated in the maintenance of tissue homeostasis by regulating renewal of normal stem-cells as well as proliferation or differentiation of progenitor cells in epithelia of adults. The first evidence that implicates hedgehog $(\mathrm{Hh})$, Notch and Wnt pathways in cancer emerged from studies showing the presence of mutations, mainly in colorectal cancer, that constitutively activated the transcriptional response and misregulates multiple growth-control functions ${ }^{2-4}$.

$\mathrm{Hh}$, Notch and Wnt pathways are vital regulators of lung embryonic development and determine the fate of the cell ${ }^{5}$. Moreover in adults they are associated to lung inflammatory processes ${ }^{6,7}$, and are activated after damage exposure by smoking ${ }^{8}$. Typically tumors associated to these embryonic signalling pathways arise from tissues such as skin, bone or colon, in which the pathways normally operate due to its fast-renewing cell rate as a result of the constant environmental exposure ${ }^{9}$. Unlike skin or colon, adult airway epithelium rarely proliferates unless injured and in adult lung it is rare to find them activated. Controversially, the murine embryonic lung molecular signature mediated by Hh, Notch and Wnt is overexpressed in human lung tumors whereas normal lung appears to later stage of mouse lung development. Furthermore, the most the aggressiveness of the lung carcinoma subtype the most the association with markers early expressed in the mouse lung development ${ }^{5}$. It is not then surprising that the hypothesis of the potential implication of Hh, Notch and Wnt in lung tumorigenesis is gradually gaining acceptance.

The idea that these embryonic molecular signatures could be associated with tumorigenesis came along with the cancer stem-cell hypothesis. Cancer stemcells as well as the normal stem-cells are under the regulation of Hh, Notch and Wnt pathways, but in a tumour context their protumorigenic characteristics including high capacity of self-renewal, multipotent differentiation, drug resistance and long lifespan relative to other cells sustain that stem-cells may initiate cancer formation as well as tumor capacity of recurrence ${ }^{10}$. Unlike other tumors ${ }^{11-13}$ no cancer stem-cells have been isolated in vivo in lung cancer to date, however, over-expression of surface markers such as adenosine triphosphate-binding cassette $(A B C)$ transporters, markers that characterize stem/progenitor population, have been identified in the adult conducting lung airway. Actually, they are called the bronchioalveolar stem-cells (BASCs) $)^{14,15}$. Moreover, in vitro regulation of this BASC cell population is linked to the expression of tumor suppressor genes in lung cancer such as MAPK, PTEN and Hh among others ${ }^{16-18}$.

Wnt, Hh and Notch among others are signal pathways that contribute to the epithelial-mesenchymal transition (EMT) which is a key step during embryonic morphogenesis. However EMT is also crucial for tumor progression to a metastatic phenotype which is to say the tumor acquisition of properties such as invasiveness and neovascularization. EMT describes the differentiation switch between an immobile epithelial cell and a contractile and motile mesenchymal cell ${ }^{19}$. Wnt, Hedgehog, Notch regulate the complex protein network to establish the mesenchymal phenotype after disassembly of the main elements of epithelial architecture ${ }^{19}$, such as desmosomes, as well as tight, adherents and gap junctions. The EMT process gives tumor cells the ability to escape and interestingly putative cancer stem-cells resembled that of mesenchymal cells and rarely stick together.

Researchers are testing therapeutic agents that hit these embryonic molecular targets highlighted by the stem-cell studies, EMT implication and the growing evidence of its existence in tumorigenesis. But this is a high-risk approach because these genes participate in healthy process of tissue renewal and toxicity could be associated with its use. Non-steroidal anti-inflammatory drugs and PPAR (peroxisome proliferator-activated receptor gamma) agonists, with the potential to inhibit the canonical Wnt signalling pathway, are candidate agents for chemoprevention ${ }^{20}$. Small molecule inhibitors (cyclopamine, CUR61414) as well as monoclonal antibodies are lead compounds targeted to Wnt and $\mathrm{Hh}$ cascades. At the moment, trials are ongoing to test the safety and effectiveness of these new compounds in different solid tumors.

\section{Lung development}

Lung development is a classic example of branching morphogenesis mediated by epithelial-mesenchymal interaction. The respiratory system arises from the ventral foregut endoderm and the process initiates with the differentiation of cells promoted by transcription factor genes such as Foxa1, Foxa2, Gata4 and Gata6, 
which are expressed early in the primitive gut tube ${ }^{21,22}$. Subsequent changes are related with local expression of several factors along the anteroposterior (AP) axis of the gut endoderm, but specially, by the homeodomain protein gene Nkx2.1 (also known as thyroid transcription factor 1, TTF-1) ${ }^{23}$. Although Nkx2.1 is the earliest known marker of the presumptive respiratory region, Nkx2.1-null mutant mice do have lungs; nevertheless, these organs are highly abnormal and consist of two main bronchi, which give rise to cystic structures, lined by columnar cells with scattered cilia. Strikingly, marker analysis shows that the epithelium fails to express any of the surfactant-protein genes typically found in the normal distal lung 24 .

The Glioma-associated oncogene homolog (Gli) and T-box (Tbx) transcription factors have been also implicated in the formation of the lung primordium. Gli1, Gli2 and Gli3 are transcriptional effectors of the $\mathrm{Hh}$ signaling pathway and sprouty (Spry) that are present in the foregut mesoderm and later in the lung mesenchyme ${ }^{24,25}$. In Gli2/Gli3 double-null mice, lung and tracheal primordium never form; other foregut derivatives develop, but are smaller than normal, and most embryos die ${ }^{26}$. Spry genes encode a family of cysteinerich proteins that interact with crucial elements of the receptor tyrosine kinase Rtk-Ras-Erk/Mapk cascade and interfere with the intensity or timing of Rtk signaling by ligands such as FGF and EGF ${ }^{27}$, clearly directed by $\mathrm{Hh}^{28}$. Bud formation can be also controlled by diffusible signals originating from epithelial cells of distal epithelium with highly expressed SHh. Data from lung organ culture and in vivo studies support the idea that $\mathrm{SHh}$ limiting lung bud outgrowth. By doing so, Hh would contribute to controlling lungs size and shape and in lungs from SHh-null mice, the epithelium develops as large cystic structures and branching morphogenesis is severely disrupted ${ }^{18}$.

The role of Wnt signaling in lung morphogenesis has also been debated. Several Wnt ligands, frizzled receptors and components of the Wnt canonical pathway, such as B-catenin, and Tcf/Lef transcription factors are present in the developing lung ${ }^{22,29}$. Activation of Wnt signaling can be monitored by detection of nuclear translocated B-catenin, and by analysis of a Wnt responsive reporter mouse, in which lacZ is expressed where the B-catenin-Lef1/Tcf complex activates the transcription of Wnt targets ${ }^{30}$. In the lung, B-catenin is expressed throughout the entire lung epithelium, however, nuclear-localized B-catenin, Tcf/Lef transcripts and lacZ-TOPGAL expression are increased in the distal lung epithelium, the sites that are actively branching $^{31,32}$. Disruption of canonical Wnt signaling at these sites by targeted deletion of B-catenin prevents distal lung buds from forming and markedly interferes with morphogenesis ${ }^{33}$.

Airway epithelial specification is far less understood, and studies have lagged behind other endodermally derived organs such as the intestine and pancreas. An early and clear divergence between neuroendocrine and non-neuroendocrine cells is mediated by the Notch pathway, analogous to inhibition in islet versus acinar cell development of the embryonic pancreas ${ }^{34,35}$. During fetal lung development, Notch signaling appears to be essential for the lung to achieve its normal size. A marked reduction in Clara cells in the small and medium sized airways apparently accounts for much of this loss. An attractive hypothesis is that Notch signaling helps to maintain a pool of less differentiated, replication-competent airway epithelial cells and precursors ${ }^{35}$.

\section{Non-small cell lung cancer developmental signaling}

\section{Notch pathway}

Notch family receptors play a critical role in maintain stem-cell viability in bone, brain, intestinal crypts and epithelium. Notch defines a cell interaction mechanism exchanging signals between neighbouring cells using 5 membrane-associated ligands (Jagged 1, Jagged 2, Delta-like/D111, D113, D114) and 4 transmembrane receptors (Notch 1 to 4). This interaction leads to cleavage of Notch receptors by metalloprotease and $\gamma$-secretase to induce the activation of transcriptional regulatory factors such as HES1, HES5, HES7, HEY1, HEY2 and HEYL, that ultimate the cell fate. Notch signalling is initiated when the extracellular domain of the receptor attaches ligands found on neighbouring cells. Thus Notch is a cell-contact depending pathway crucial to morphogenesis $^{36}$. Quantitative expression studies from the developing lung demonstrate a progressive increase in Notch1-4, D111, and Jagged 1 mRNAs from early embryo to adulthood ${ }^{37}$. RNA in situ hybridization and 
immunohistochemistry studies suggest that Notch1 is expressed in the distal lung endoderm at least as early as after eleven weeks of pregnancy and persist through fetal development ${ }^{38}$.

The effects of Notch are context dependent and inhibition of Notch signals is likely to have multitude of effects in different cell types ${ }^{39}$. Accumulated preclinical data in several tumors supports Notch as a pro-oncogene resulting in tumor growth and differentiation ${ }^{40-42}$. However, in some cells such as epidermal keratinocytes it can work as a tumor suppressor ${ }^{43,44}$. To enhance the complexity of Notch network it is worth it to say that different Notch receptors may have opposite effects ${ }^{1-4}$.

Although data regarding the role of the Notch pathway in human lung cancer are still limited, fetal lung developmental studies suggest that Notch plays a critical role in regulating airway epithelial development ${ }^{45}$. Interestingly hypoxia, which is associated to smoke habit, dramatically elevates Notch-1 in lung tumor cell lines and sensitizes them to inhibition ${ }^{46}$ strengthen the role of Notch in lung cancer. The high expression levels of Notch in some tumors such as lung carcinoma and mesothelioma sustain its role as an oncogene. However, its absence in other tumors such as carcinoid tumours indicates that the role of Notch signalling is dependent on its cellular context (reviewed in neuroendocrine and small cell carcinoma of the lung).

Elevated Notch receptors, Jagged1 and transcriptional target genes (HES1, HEY1) have been described in non-small cell lung cancer (NSCLC) and mesothelioma cell lines as well as in frozen tumor samples ${ }^{47,48}$. The blockade of Notch-3 using gamma-secretase inhibits lung tumor growth both in vitro and in vivo using mouse xenograft models ${ }^{47}$. In addition, Notch-3 overexpression in NSCLC cell lines has been associated with a specific somatic acquired chromosomal translocation at $19 p^{15,19,48}$. Somatic mutations or chromosomal deletions are normally associated to tumor suppressor genes or dominant oncogenes. Unlike hematologic malignancies, these mutations are not frequently found in epithelial lung tumor malignancies. The evidence of this genetic abnormality in aggressive metastasic lung carcinoma and its association with Notch-3 expression gives more insight about the importance of Notch family members in lung tumorigenesis.

Notch signalling has important cross talk interactions with other pathways. Ras signalling, which is well known to be deregulated in NSCLC, activates Notch signaling and wild-type Notch-1 is necessary to maintain the neoplastic phenotype in human Ras-transformed cells ${ }^{49}$. However, the expression of Notch-1 receptors in human lung adenocarcinoma cell lines inhibited cell growth through induction of cell cycle arrest suggesting that Notch signalling may function as a tumor suppressor in human lung adenocarcinoma ${ }^{50}$. In addition, Notch has an essential role in vascular differentiation and homeostasis in normal adults by repressing endothelial cell proliferation in normal tissue ${ }^{51}$. Two Notch ligands, DII 4 and Jagged 1, are overexpress in endothelial tumor cells and they have been implicated in tumor angiogenesis ${ }^{52}$. Notch ligand DII 4 expression is correlated with VEGF levels ${ }^{53}$ and its inhibition induce a chaotic overgrowth of the tumor vasculature affecting the efficient delivery of blood therefore affecting tumor growth ${ }^{54}$. In NSCLC, angiogenesis is a target for therapeutic intervention and molecular antibodies have been validated as standard treatment of advanced disease associated to chemotherapy, consequently Notch ligands inhibition could represent an alternative to VEGF inhibitors in NSCLC treatment.

Notch signalling is also crucial for the EMT, which is associated with increased cell motility, and invasiveness ${ }^{55,56}$. In NSCLC, EMT has been associated to sensitivity to epidermal growth factor receptor (EGFR) inhibitors. Erlotinib is a tyrosine kinase inhibitor that has been approved for second line treatment in advanced NSCLC; its sensitivity in NSCLC patients is well known to be associated to mutations at EGFR, mainly at exon 19 and exon $21^{57}$. Interestingly, in vitro sensitive NSCLC cell lines express epithelial markers such as E-cadherin (ECAD) whereas non-sensitive ones express mesenchymal markers such as vimentine or fibronectine. In a subanalysis of the Tribute trial, patients with ECAD positive tumors had better outcome when treated with chemotherapy in combination with Erlotinib. Therefore, a mesenchymal phenotype lacking cell polarity defined loss of cell sensitivity to EGFR tyrosine-kinase inhibitors $(\mathrm{TKI})^{58}$. Preliminary data indicates that inhibiting Notch by using $\gamma$-secretase inhibitor MRK003 reduces tumor growth in vivo and enhance tumor sensitivity to $\mathrm{TK}^{58}$. Consequently, the development of new molecules targeting Notch could be a new strategy to overcome the resistance to TKIs associated to epithelial-to-mesenchymal transition. 


\section{Hedgehog}

The Hedgehog ( $\mathrm{Hh}$ ) family of secreted proteins which includes Sonic (SHh), Indian (Ihh) and Desert (Dhh), play an important role in mammalian development morphogenesis and the regulation of stem-cell fates $^{59}$. After binding to tumor-suppressor Patched (Ptc) receptor signalling is activated through proto-oncogene Smoothened (Smo) derepression ${ }^{60}$ which ultimately activates the Gli family of transcription factors (Gli 1-3) ${ }^{59}$. Hh pathway mediates epithelial-mesenchymal interactions during lung development by signalling to adjacent lung mesenchyma as indicated by expression of the $\mathrm{Hh}$ receptor and Ptch ${ }^{28,61}$. In addition, loss of the Hh protein function results in severe lung defects associated with failure of branching morphogenesis ${ }^{18}$. Deregulation of Hh pathway has been described in various human cancers, including medulloblastomas, pancreas, prostate and also small cell lung cancer (SCLC) $)^{62-66}$, and it has been estimated that $25 \%$ of human tumors require $\mathrm{Hh}$ signalling to keep their viability ${ }^{67,68}$.

The involvement of $\mathrm{Hh}$ in lung malignancies has been widely described in SCLC66. Whereas SCLC is dependent on activation of Hedgehog signaling (reviewed afterwards), its role in NSCLC is less clarified. However in adult, constitutive Hh signalling seems to be restricted to small number of cells at the basal layer of the bronchial epithelium at low levels ${ }^{66}$. The normally quiescent airway epithelial compartment uses the $\mathrm{Hh}$ pathway to repopulate itself when challenged by injury such as the induced by cigarette smoke ${ }^{8}$. There is an extensive activation of the Hh pathway within the airway epithelium during repair of acute airway injury and immediately precedes neuroendocrine differentiation which is considered a potential progenitor of epithelial regeneration ${ }^{69}$

Chronic smoke exposure induces phenotypic changes characteristic of tumor cells by transformation of human primary bronchial epithelial cells. Treatment with inhibitors of the Wnt and Hh pathways can modulate growth tumor arising from smoke-transformed bronchial epithelial cells in mice ${ }^{8}$. However the cigarette smoke activation of this pathway is not sufficient to induce full malignant transformation of lung cells and other smoke-induced genotypic changes are also required to tiger such malignant transformation. Some subset of NSCLC cell lines require constitutive activation of Hh pathway $66,70,71$. Nevertheless, the frequency of
Hh activation in NSCLC varies among reports; among those NSCLC cell lines that require Hh activity some could be insensitive to $\mathrm{Hh}$ inhibition as a consequence of overexpression of the downstream transcription factor $\mathrm{Gli}^{71}$. Therefore its role in NSCLC remains uncertain.

\section{Wnt}

The Wnt signalling pathway was first described for its role in a range of embryonic events. It was afterwards when it was first described its involvement in cancer by the identification of Wnt-1 as Int-1, a proto-oncogene in mammary tumors activated by integration of the mouse mammary tumor virus (MTV) ${ }^{72}$. Wht signalling is compound by extracellular ligand Wnts and a group of membrane members which includes the low-density lipoprotein receptor-related protein (LRP) and Frizzled (Fz). In the absence of ligands (Off position), $\beta$-catenin is degradated via proteasoma by a cytoplasmatic destruction complex set up by the adenomatous poliposis coli $(A P C)$, Axin and the glycogen synthase kinase (GSK)$3 \beta$. When ligands bind to transmembrane receptors (On position), the destruction complex is disrupted by Dishevelled, a cytoplasmatic protein, stabilizing cytoplasmatic $\beta$-catenin levels which finally activate multiple nuclear transcription factors that end up with cellular growth?.

Along with $\mathrm{Hh}$ and Notch, Wnt plays crucial roles in lung morphogenesis. Knockout mice studies demonstrated the importance of Wnts in lung development $^{73-75}$. Moreover $W n t / \beta$-catenin pathway is also activated in lung inflammatory processes ${ }^{76}$.

Recently atypical adenomatous hyperplasia $(A A H)$, a precursor lesion of lung adenocarcinoma, has been associated at early stages with Wnt antagonist silencing by promoter hypermethylation ${ }^{7}$ and along with $\mathrm{Hh}$, Wnt pathway mediates smoke-induced tumorigenesis in lung.

Several mutations at the APC or Axin have been described in some solid tumors supporting an oncogene aberrant activation addiction ${ }^{77-81}$. However in other tumors, such as NSCLC, Wnt activation may not be associated to constitutive mutations but a disbalanced activation of Wnt components by over or under-expression $^{82-86}$. Nowadays several data supports an aberrant activation of Wnt signalling in lung tumorigenesis.

Several Wnt ligands, proteins that signal via interaction with Fz membrane receptor, are overexpress in 
NSCLC and mesothelioma cell lines and tissue samples and its inhibition using siRNA or specific monoclonal antibody induces apoptosis ${ }^{82,83,87}$. Some reports have associated overexpression of this ligands with tumor proliferation and poor prognosis in NSCLC patients ${ }^{88}$. Whereas some Wnts (Wnt 1-2) are upregulated others like Wnt-7 are downregulated in cell lines as tumor samples. Moreover, this down-regulation comes along with E-cadherin loss which is associated with tumor de-differentiation, invasion, and metastasis ${ }^{89}$.

Dishevelled (Dvl) proteins, cytoplasmatic mediators of Wnt signalling, are overexpressed in NSCLC and mesothelioma tissue samples compared to matched normal tissues ${ }^{90,91}$. In addition, inhibition of these proteins induces growth arrest dependent on Tcf-transcription. Recently the expression levels of all three Dvl proteins was screened for a panel of 113 NSCLC and found to be overexpress in 53\% of the samples while no expression was found in normal adult bronchial and alveolar epithelia. Interestingly Dvl expression was significantly higher in adenocarcinomas than in squamous carcinomas and was associated with poor tumor differentiation ${ }^{92}$. Unlike other tumors mutations at $\beta$-catenin or APC are uncommon in NSCLC ${ }^{93,94}$. Conversely some repots associate increased expression of $\beta$-catenin with a high proliferative index and worse prognosis ${ }^{95}$. It is interesting to point out that there is a positive correlation between activated EGFR mutations and nuclear accumulation of $\beta$-catenin ${ }^{96}$. Based on previous reports, the role of $\beta$-catenin in NSCLC by itself seems to be less significant than in other tumors such as colorectal carcinoma.

The family of Wnt antagonists includes the sFRP family, Wnt inhibitory factor (WIF)-1, Cerberus and the Dickkopf (Dkk) family. They are secreted proteins that modulated Wnt activity by binding to Wnt molecules (sFRP, WIF-1, Cerberus) or by direct binding to the receptor LRP (Dkk). They have been widely studied in NSCLC and several reports sustain its involvement in lung cancer pathogenesis. WIF-1 expression is downregulated by promoter hypermethylation in NSCLC as well as mesothelioma tumor samples ${ }^{84,97}$. Furthermore restoration of Wnt inhibitory factor function by transfection of an expression vector containing the Wnt inhibitory factor gene inhibits lung cancer cell growth both in vitro and in vivo ${ }^{95}$. Expression of secreted frizzled-related proteins, another endogenous modulator of Wnt signaling, is also silenced in NSCLC and mesothelioma primary tissues and cell lines ${ }^{98}$ and it is found to be hypermethylated in $80 \%$ of the mesothelioma tissue samples. Dkk secreted proteins as well as their counterparts are downregulated many cell lines including lung carcinoma ${ }^{99}$. Therefore epigenetic changes in the Wnt family of antagonists seem to be a crucial mechanism in thoracic malignances. Taken together, the results show an upstream activation of several Wnt proteins in NSCLC and uphold an important spring of potential targets to develop new therapeutic agents in lung cancer treatment.

\section{Neuroendocrine and small cell lung carcinomas developmental signaling}

As we mentioned, the complexity of Notch signaling at both the receptor and ligand levels represents a big challenge toward understanding the role of these protein interactions in normal lung and SCLC development. Quantitative expression studies from the developing lung demonstrate a progressive increase in Notch1-4, DIl1, and Jagged1 mRNAs from early embryo to adulthood ${ }^{37}$. RNA in situ hybridization and immunohistochemistry studies suggest that Notch1 is expressed in the distal lung endoderm at least as early as eleven week of pregnancy and persists through fetal development ${ }^{38}$. None of the four Notch receptors are known to be expressed in neuroendocrine cells, but specific expression patterns for the Notch ligands can be observed in the mesenchymal and neuroendocrine compartments ${ }^{100}$ Jag1 expression can be observed in lung mesenchyme, and prominently in lung vessels of SCLC, but its significance are unknown ${ }^{38}$.

Mammalian bombesin-like peptide (BLP) was identified as the first neuropeptide localized to pulmonary neuroendocrine cells ${ }^{101}$; cells containing BLP immunoreactivity are present at high numbers in human newborn and fetal lung, and appears to be indirectly linked with Notch1 expression via tumor necrosis factor-a (TNF) ${ }^{102}$. Recently, Shan et al. ${ }^{103}$ demonstrated that decreased Notch signaling be one mechanism contributing to the sustained increase in gene expression and the ultimate neuroendocrine 
phenotypic induction; nevertheless, as there is no single master regulator of neuroendocrine cell differentiation the regulatory effect of Notch over SCLC development remains unclear.

Activated Notch1 and Notch2, but not Hes1 caused a potent $\mathrm{G1}$ arrest in SCLC cells, accompanied by marked up regulation of p21waf1/cip1. As expected, these researchers also found abundance of $\mathrm{p} 53^{104}$. The known effect of Notch1 to up regulate p21 could not be solely responsible for the growth arrest however, as it was observed in an $\mathrm{Rb}$ mutant context $(\mathrm{NCl}$ H209 cells) typifying the majority of SCLC. It is unclear whether lower levels of Notch signaling also would confer a growth arrest in SCLC ${ }^{105}$. Until today, there is no preclinical evidence to explore Notch-based therapies as a complement to either conventional cytotoxic chemotherapy or other targeted pathway inhibition strategies in SCLC scenario.

\section{Hedgehog}

Recently, Watkins et al. observed a marked expression of both SHh ligand and Gli1 in neuroendocrine cells that are normally implicated in the regulation of airway epithelial regeneration ${ }^{66}$. Furthermore, they found a high expression of $\mathrm{Hh}$ proteins and consecutive activation of the pathway in the primitive lung endoderm ${ }^{66,69,106}$. To establish a posible SHh pathway activation in adult bronchial epithelium the same group used mice in which one copy of Ptch is replaced in-frame with the $\beta$-galactosidase ( $\beta$-gal) gene by homologous recombination, however, they only found a small number of cells expressing the marker in the basal layer of the adult bronchial epithelium ${ }^{66}$. This data validate the hypothesis of a neuroendocrine precursor within the airway epithelial compartment that responds to a SHh signal elaborated by neighboring airway epithelial cells ${ }^{107}$. Previous findings were confirmed by analysis of seven human SCLC cell lines which expressed both $\mathrm{Hh}$ and Gli1 proteins with a linear correlation of Ptch messenger RNA expression ${ }^{66}$. This concept was proved evaluating whether ligand driven Hh pathway activation promotes growth of SCLC; inhibition of SHh ligand activity in $\mathrm{NCl}-\mathrm{H} 249$ and $\mathrm{NCl}-\mathrm{H} 1618 \mathrm{SCLC}$ culture cells with the 5E1-SHh-N monoclonal antibody resulted in growth inhibition demonstrating that growth of SCLC cells in vitro is dependent on ligand-mediated activation of the Hh pathway ${ }^{108}$. Another study investigating the expression of Gli1 in SCLC tissue reported that 85\% of SCLC express Gli1 and more than $60 \%$ have a medium to strong expression correlating with increased Hh signaling ${ }^{109}$

Treatment of NCl-H249 SCLC cells with cyclopamine (a molecule that blocks the oncogenic effect of mutations of Ptch and specifically inhibits the Hh pathway) resulted in significant cancer cell inhibition and repression of genes like BMP4, a morphogen and putative target of Hh expressed in lung epithelial embryogenesis ${ }^{110}$, and nestin, an intermediate filament characteristic of neural stem cells in medulloblastoma ${ }^{62}$. These changes in gene expression suggest that $\mathrm{Hh}$ contribute to maintain a progenitor cell in SCLC by paracrine stimuli of of their surrounding environment.

Moreover, Lemjabbar-Alaoui et al. demonstrated that $\mathrm{Hh}$ activation occurs in cells repeatedly exposed to smoke for $\geq 7$ days in immortalized BEAS2B cells (an SV40-immortalized bronchial epithelial cell line) and $\geq$ 2 days in primary normal human bronchial epithelial cells ${ }^{8}$. By far, almost all cellular activity of SHh signaling after tobacco smoke exposure are related with cyclin$D$ and cyclin-E, two proteins vital for the G1-to-S cell cycle transition in SCLC ${ }^{111}$. Hh signaling activates the mitosis promoting factor by increasing the intranuclear availability of cyclin $\mathrm{B}^{112,113}$ and also opposes normal stimuli for epithelial cell cycle arrest (by inhibiting P21) and promotes tumor cell growth ${ }^{114}$. In association, SHh signaling inhibits the primary regulator of apoptosis, the p53 tumor suppressor gene ${ }^{115}$.

The availability of the $\mathrm{Hh}$ ligand for signaling is regulated by the expression of HIP on the cell surface of $\mathrm{Hh}$ responsive cells. Activation of the $\mathrm{Hh}$ pathway causes an increased expression of the HIP via a negative feedback mechanism, which means that HIP is the principal antagonist of Hh signaling. Experimental models studying HIP knockout mice confirmed augmented Hh signaling; in opposite it appear to be down-regulation of HIP in endothelial cells during angiogenesis ${ }^{116}$. These findings suggest a reduced HIP expression in tumors including SCLC. SHh was also shown to induce the expression of angiopoietins I and II and the family of VEGF signaling proteins from mesenchymal cells, highlighting the significance of tumor associated fibroblasts in combination with Hh signaling to mediate blood vessel formation ${ }^{117}$. 


\section{Wnt}

The proneural basic-helix-loop-helix protein achaetescute homologue 1 (ASH1) is expressed in a very limited spectrum of normal and cancerous cells in a lineage specific manner, including normal pulmonary neuroendocrine cells and lung cancer cells with neuroendocrine features. This protein was found to inactivate DKK1 and $D K K 3$, negative regulators of $\mathrm{Wnt} / \beta$-catenin signaling, E-cadherin, and integrin $\beta 1$ through ASH1-mediated deacetylation and repressive trimethylation of lysine 27 (H3K27me3) of histone H3 in the promoter regions of DKK1 and E-cadherin ${ }^{118}$. This information change concept that Wnt affects only the evolution of NSCLC, because $\mathrm{E}$-cadherin promotes cell-cell interactions and sequesters $\beta$-catenin in the cell membrane, whereas reduced $\mathrm{E}$-cadherin expression has been postulated to play a role in cell migration and metastasis, as well as anchorage independence ${ }^{119}$. Now, we know why E-cadherin is silenced in including lung cancers with neuroendocrine features ${ }^{120}$.

Pelosi et al. evaluate the expression of E-cadherin/ beta-catenin in 210 neuroendocrine tumors, including 96 typical carcinoids, 35 atypical carcinoids, 49 large cell neuroendocrine carcinomas, and 30 small cell lung carcinomas finding a homogeneous beta-catenin expression in all tumors and E-cadherin in most tumors, with the exception of 3\% of SCLCs and $9 \%$ of atypical carcinoids ${ }^{121}$. Furthermore, a disarrayed E-cadherin distribution pattern was associated with the pathologic lymph node classification and the number of involved lymph nodes. Multivariate analysis confirmed that a disarrayed E-cadherin or beta-catenin pattern was an independent predictor of lymph node metastases in patients with carcinoid tumors. Another recent preclinical study support this data reporting clear suppression of ASH1 expression through ASH1-RNAi-induced G2-M cell cycle arrest and apoptotic cell death; the induction of apoptosis was associated with activation of caspases, implying that ASH1 may play a role in the inhibitory regulation of cell death. Although the molecular mechanisms of induction of cell cycle arrest and apoptosis by ASH1-RNAi remain to be elucidated, this findings imply a role for ASH1 in the regulation of cell proliferation and cell fate specifically in lung cancers with neuroendocrine features ${ }^{118}$.

\section{Conclusions}

Hedgehog Notch and Wnt may be the connection between a primitive embryonic state and the complex architecture of lung cancer. Although this could be seen as a simplistic conclusion, several reports associated these signaling pathways with lung malignances. However, we must keep in mind that the final objective is to translate this knowledge into clinical practice, which is to say, the development of target therapies to improve the outcome for lung cancer patients.

\section{References}

1. Parkin DM, Bray F, Ferlay J, Pisani P. Global cancer statistics, 2002. CA Cancer J Clin. 2005;55(2):74-108.

2. Morin PJ, Sparks $A B$, Korinek $V$, Barker $N$, Clevers $H$, Vogelstein $B$, et al. Activation of beta-catenin-Tcf signaling in colon cancer by mutations in beta-catenin or APC. Science, 1997;275(5307):1787-90.

3. Dahmen RP, Koch A, Denkhaus D, Tonn JC, Sörensen N, Berthold F, et al. Deletions of AXIN1, a component of the WNT/ wingless pathway, in sporadic medulloblastomas. Cancer Res, 2001;61(19):7039-43.

4. Korinek V, Barker N, Morin PJ, van Wichen D, de Weger R, Kinzler KW, et al. Constitutive transcriptional activation by a beta-catenin-Tcf complex in APC-/- colon carcinoma. Science. 1997;275(5307):1784-7.

5. Liu $H$, Kho AT, Kohane IS, Sun Y. Predicting survival within the lung cancer histopathological hierarchy using a multi-scale genomic model of development. PLoS Med. 2006;3(7):e232.
6. Kitagawa H, Goto A, Niki T, Hironaka M, Nakajima J, Fukayama M. Lung adenocarcinoma associated with atypical adenomatous hyperplasia. A clinicopathological study with special reference to smoking and cancer multiplicity. Pathol Int. 2003;53(12):823-7.

7. Licchesi JD, Westra WH, Hooker CM, Machida EO, Baylin SB, Herman JG. Epigenetic alteration of Wnt pathway antagonists in progressive glandular neoplasia of the lung. Carcinogenesis. 2008;29(5):895-904.

8. Lemjabbar-Alaoui $H$, Dasari $V$, Sidhu SS, Mengistab A, Finkbeiner W, Gallup M, et al. Wnt and Hedgehog are critical mediators of cigarette smoke-induced lung cancer. PLoS One. 2006;1:e93.

9. Taipale J, Beachy PA. The Hedgehog and Wnt signalling pathways in cancer. Nature. 2001;411(6835):349-54.

10. Reya T, Morrison SJ, Clarke MF, Weissman IL. Stem cells, cancer, and cancer stem cells. Nature. 2001;414:105-111. 
11. Bonnet $D$, Dick JE. Human acute myeloid leukemia is organized as a hierarchy that originates from a primitive hematopoietic cell. Nat Med. 1997;3(7):730-7.

12. Al-Hajj M, Wicha MS, Benito-Hernandez A, Morrison SJ, Clarke MF. Prospective identification of tumorigenic breast cancer cells. Proc Natl Acad Sci USA. 2003;100(7):3983-8.

13. Collins AT, Berry PA, Hyde C, Stower MJ, Maitland NJ. Prospective identification of tumorigenic prostate cancer stem cells. Cancer Res. 2005;65(23):10946-51.

14. Kim CF, Jackson EL, Woolfenden $A E$, Lawrence $S$, Babar I, Vogel $S$, et al. Identification of bronchioalveolar stem cells in normal lung and lung cancer. Cell. 2005;121(6):823-35.

15. Ling TY, Kuo MD, Li CL, Yu AL, Huang YH, Wu TJ, et al. Identification of pulmonary Oct-4+ stem/progenitor cells and demonstration of their susceptibility to SARS coronavirus (SARS-CoV) infection in vitro. Proc Natl Acad Sci USA. 2006;103(25):95305.

16. Ventura JJ, Tenbaum S, Perdiguero E, Huth M, Guerra C, Barbacid $M$, et al. p38alpha MAP kinase is essential in lung stem and progenitor cell proliferation and differentiation. Nat Genet. 2007;39(6):750-8

17. Yanagi S, Kishimoto H, Kawahara K, Sasaki T, Sasaki M, Nishio $\mathrm{M}$, et al. Pten controls lung morphogenesis, bronchioalveolar stem cells, and onset of lung adenocarcinomas in mice. J Clin Invest. 2007:117(10):2929-40.

18. Pepicelli CV, Lewis PM, McMahon AP. Sonic hedgehog regulates branching morphogenesis in the mammalian lung. Curr Biol. 1998;8(19):1083-6.

19. Moustakas $\mathrm{A}$, Heldin $\mathrm{CH}$. Signaling networks guiding epithelial-mesenchymal transitions during embryogenesis and cancer progression. Cancer Sci. 2007;98(10):1512-20.

20. Winn RA, Van Scoyk M, Hammond M, Rodriguez K, Crossno JT $J \mathrm{~J}$, Heasley LE, et al. Antitumorigenic effect of Wnt 7a and Fzd 9 in non-small cell lung cancer cells is mediated through ERK5-dependent activation of peroxisome proliferator-activated receptor gamma. J Biol Chem. 2006;281(37):26943-50.

21. Kuo CT, Morrisey EE, Anandappa R, Sigrist $K$, Lu MM, Parmacek MS, et al. GATA4 transcription factor is required for ventral morphogenesis and heart tube formation. Genes Dev. 1997;11(8):1048-60

22. Lako M, Strachan T, Bullen P, Wilson DI, Robson SC, Lindsay S. Isolation, characterisation and embryonic expression of WNT11, a gene which maps to $11 \mathrm{q} 13.5$ and has possible roles in the development of skeleton, kidney and lung. Gene. 1998;219(12):101-10

23. Kimura $S$, Hara $Y$, Pineau $T$, Fernandez-Salguero $P$, Fox $C H$, Ward JM, et al. The T/ebp null mouse: thyroid-specific enhancer-binding protein is essential for the organogenesis of the thyroid, lung, ventral forebrain, and pituitary. Genes Dev. 1996;10(1):60-9.

24. Hui CC, Slusarski D, Platt KA, Holmgren R, Joyner AL. Expression of three mouse homologs of the Drosophila segment polarity gene cubitus interruptus, Gli, Gli-2, and Gli-3, in ectodermand mesoderm-derived tissues suggests multiple roles during postimplantation development. Dev Biol. 1994;162(2):402-13.

25. Motoyama J, Liu J, Mo R, Ding Q, Post M, Hui CC. Essential function of Gli2 and Gli3 in the formation of lung, trachea and oesophagus. Nat Genet. 1998;20(1):54-7.

26. Chapman DL, Garvey N, Hancock S, Alexiou M, Agulnik SI, Gibson-Brown JJ, et al. Expression of the T-box family ge- nes, Tbx1-Tbx5, during early mouse development. Dev Dyn. 1996;206(4):379-90.

27. Kim HJ, Bar-Sagi D. Modulation of signalling by Sprouty: a developing story. Nat Rev Mol Cell Biol. 2004;5(6):441-50.

28. Bellusci S, Furuta $Y$, Rush MG, Henderson R, Winnier G, Hogan BL. Involvement of Sonic hedgehog (Shh) in mouse embryonic lung growth and morphogenesis. Development. 1997;124(1):53-63

29. Zakin LD, Mazan S, Maury M, Martin N, Guénet JL, Brûlet P. Structure and expression of Wnt13, a novel mouse Wnt2 related gene. Mech Dev. 1998;73(1):107-16.

30. Nelson WJ, Nusse R. Convergence of Wnt, beta-catenin, and cadherin pathways. Science. 2004;303(5663):1483-7.

31. Okubo T, Hogan BL. Hyperactive Wnt signaling changes the developmental potential of embryonic lung endoderm. J Biol. 2004;3(3):11

32. Dean $C H$, Miller LA, Smith $A N$, Dufort $D$, Lang RA, Niswander LA. Canonical Wnt signaling negatively regulates branching morphogenesis of the lung and lacrimal gland. Dev Biol. 2005;286(1):270-86.

33. De Langhe SP, Sala FG, Del Moral PM, Fairbanks TJ, Yamada KM, Warburton D, et al. Dickkopf-1 (DKK1) reveals that fibronectin is a major target of Wnt signaling in branching morphogenesis of the mouse embryonic lung. Dev Biol. 2005;277(2):316-31.

34. Esni F, Ghosh B, Biankin AV, Lin JW, Albert MA, Yu X, et al. Notch inhibits Ptf1 function and acinar cell differentiation in developing mouse and zebrafish pancreas. Development. 2004;131(17):4213-24.

35. Hald J, Hjorth JP, German MS, Madsen OD, Serup P, Jensen J. Activated Notch1 prevents differentiation of pancreatic acinar cells and attenuate endocrine development. Dev Biol. 2003;260(2):426-37

36. Artavanis-Tsakonas S, Rand MD, Lake RJ. Notch signaling: cell fate control and signal integration in development. Science. 1999;284(5415):770-6

37. Itoh K, Antipova A, Ratcliffe MJ, Sokol S. Interaction of dishevelled and Xenopus axin-related protein is required for wnt signal transduction. Mol Cell Biol. 2000;20(6):2228-38.

38. Post LC, Ternet M, Hogan BL. Notch/Delta expression in the developing mouse lung. Mech Dev. 2000 Nov;98(1-2):95-8.

39. Rizzo P, Osipo C, Foreman K, Golde T, Osborne B, Miele L. Rational targeting of Notch signaling in cancer. Oncogene. 2008;27(38):5124-31

40. Roy M, Pear WS, Aster JC. The multifaceted role of Notch in cancer. Curr Opin Genet Dev. 2007;17(1):52-9.

41. Reedijk M, Odorcic S, Chang L, Zhang H, Miller N, McCready $\mathrm{DR}$, et al. High-level coexpression of JAG1 and NOTCH1 is observed in human breast cancer and is associated with poor overall survival. Cancer Res. 2005:65(18):8530-7.

42. Pinnix CC, Herlyn M. The many faces of Notch signaling in skinderived cells. Pigment Cell Res. 2007;20(6):458-65.

43. Nicolas M, Wolfer A, Raj K, Kummer JA, Mill P, van Noort M, et al. Notch1 functions as a tumor suppressor in mouse skin. Nat Genet. 2003;33(3):416-21.

44. Koch U, Radtke F. Notch and cancer: a double-edged sword. Cell Mol Life Sci. 2007;64(21):2746-62.

45. Tsao PN, Chen F, Izvolsky KI, Walker J, Kukuruzinska MA, Lu J, et al. Gamma-secretase activation of notch signaling regulates 
the balance of proximal and distal fates in progenitor cells of the developing lung. J Biol Chem. 2008;283(43):29532-44.

46. Chen $Y$, De Marco MA, Graziani I, Gazdar AF, Strack PR, Miele $\mathrm{L}$, et al. Oxygen concentration determines the biological effects of NOTCH-1 signaling in adenocarcinoma of the lung. Cancer Res. 2007;67(17):7954-9.

47. Konishi J, Kawaguchi KS, Vo H, Haruki N, Gonzalez A, Carbone DP, et al. Gamma-secretase inhibitor prevents Notch3 activation and reduces proliferation in human lung cancers. Cancer Res. 2007;67(17):8051-7.

48. Dang TP, Gazdar AF, Virmani AK, Sepetavec $T$, Hande $K R$, Minna JD, et al. Chromosome 19 translocation, overexpression of Notch3, and human lung cancer. J Natl Cancer Inst. 2000;92(16):1355-7.

49. Weijzen S, Rizzo P, Braid M, Vaishnav R, Jonkheer SM, Zlobin $A$, et al. Activation of Notch-1 signaling maintains the neoplastic phenotype in human Ras-transformed cells. Nat Med. 2002;8(9):979-86.

50. Zheng Q, Qin H, Zhang H, Li J, Hou L, Wang $H$, et al. Notch signaling inhibits growth of the human lung adenocarcinoma cell line A549. Oncol Rep. 2007;17(4):847-52.

51. Dou GR, Wang YC, Hu XB, Hou LH, Wang CM, Xu JF, et al. RBP$J$, the transcription factor downstream of Notch receptors, is essential for the maintenance of vascular homeostasis in adult mice. FASEB J. 2008;22(5):1606-17.

52. Mailhos C, Modlich U, Lewis J, Harris A, Bicknell R, Ish-HorowiCz D. Delta4, an endothelial specific notch ligand expressed at sites of physiological and tumor angiogenesis. Differentiation. 2001;69(2-3):135-44.

53. Patel NS, Li JL, Generali D, Poulsom R, Cranston DW, Harris AL. Up-regulation of delta-like 4 ligand in human tumor vasculature and the role of basal expression in endothelial cell function. Cancer Res. 2005;65(19):8690-7.

54. Noguera-Troise I, Daly C, Papadopoulos NJ, Coetzee S, Boland P, Gale NW, et al. Blockade of Dll4 inhibits tumour growth by promoting non-productive angiogenesis. Nature. 2006;444(7122):1032-7.

55. Sahlgren C, Gustafsson MV, Jin S, Poellinger L, Lendahl U. Notch signaling mediates hypoxia-induced tumor cell migration and invasion. Proc Natl Acad Sci USA. 2008;105(17):6392-7.

56. Timmerman LA, Grego-Bessa J, Raya A, Bertrán E, Pérez-Pomares JM, Díez J, et al. Notch promotes epithelial-mesenchymal transition during cardiac development and oncogenic transformation. Genes Dev. 2004;18(1):99-115.

57. Pao W, Ladanyi M, Miller VA; Lung Cancer Oncogenome Group. Erlotinib in lung cancer. N Engl J Med. 2005;353(16):1739-41; author reply 1739-1741.

58. Einhorn LH, Bonomi $\mathrm{P}$, Bunn PA Jr, Camidge DR, Carbone DP, Choy $\mathrm{H}$, et al. Summary report 7th Annual Targeted Therapies of the Treatment of Lung Cancer. J Thorac Oncol. 2008;3(5):54555 .

59. Ingham PW, McMahon AP. Hedgehog signaling in animal development: paradigms and principles. Genes Dev. 2001;15(23):3059-87.

60. Ogden SK, Ascano M Jr, Stegman MA, Robbins DJ. Regulation of Hedgehog signaling: a complex story. Biochem Pharmacol. 2004;67(5):805-14.

61. Pepinsky RB, Rayhorn P, Day ES, Dergay A, Williams KP, Galdes $A$, et al. Mapping sonic hedgehog-receptor interactions by steric interference. J Biol Chem. 2000;275(15):10995-1001.
62. Berman DM, Karhadkar SS, Hallahan AR, Pritchard Jl, Eberhart CG, Watkins DN, et al. Medulloblastoma growth inhibition by hedgehog pathway blockade. Science. 2002;297(5586):1559-61.

63. Thayer SP, di Magliano MP, Heiser PW, Nielsen CM, Roberts DJ, Lauwers GY, et al. Hedgehog is an early and late mediator of pancreatic cancer tumorigenesis. Nature. 2003;425(6960):851-6.

64. Fan L, Pepicelli CV, Dibble CC, Catbagan W, Zarycki JL, Laciak R, et al. Hedgehog signaling promotes prostate xenograft tumor growth. Endocrinology. 2004;145(8):3961-70.

65. Kubo M, Nakamura M, Tasaki A, Yamanaka N, Nakashima $H$, Nomura $\mathrm{M}$, et al. Hedgehog signaling pathway is a new therapeutic target for patients with breast cancer. Cancer Res 2004;64(17):6071-4.

66. Watkins DN, Berman DM, Burkholder SG, Wang B, Beachy PA, Baylin SB. Hedgehog signalling within airway epithelial progenitors and in small-cell lung cancer. Nature. 2003;422(6929):313-7.

67. Lum L, Beachy PA. The Hedgehog response network: sensors, switches, and routers. Science. 2004;304(5678):1755-9.

68. Toftgard R. Hedgehog signalling in cancer. Cell Mol Life Sci. 2000;57(12):1720-31.

69. Reynolds SD, Hong KU, Giangreco A, Mango GW, Guron $C$, Morimoto $Y$, et al. Conditional clara cell ablation reveals a self-renewing progenitor function of pulmonary neuroendocrine cells. Am J Physiol Lung Cell Mol Physiol. 2000;278(6):L1256-63.

70. Fujita E, Khoroku Y, Urase K, Tsukahara T, Momoi MY, Kumagai $\mathrm{H}$, et al. Involvement of Sonic hedgehog in the cell growth of LK-2 cells, human lung squamous carcinoma cells. Biochem Biophys Res Commun. 1997;238(2):658-64.

71. Yuan Z, Goetz JA, Singh S, Ogden SK, Petty WJ, Black CC, et al. Frequent requirement of hedgehog signaling in non-small cell lung carcinoma. Oncogene. 2007;26(7):1046-55.

72. Nusse R, Varmus HE. Many tumors induced by the mouse mammary tumor virus contain a provirus integrated in the same region of the host genome. Cell. 1982;31(1):99-109.

73. Yamaguchi TP, Bradley A, McMahon AP, Jones S. Wnt5a pathway underlies outgrowth of multiple structures in the vertebrate embryo. Development. 1999;126(6):1211-23.

74. Weidenfeld J, Shu W, Zhang L, Millar SE, Morrisey EE. The WNT7b promoter is regulated by TTF-1, GATA6, and Foxa2 in lung epithelium. J Biol Chem. 2002;277(23):21061-70.

75. Li C, Xiao J, Hormi K, Borok Z, Minoo P. Wnt5a participates in distal lung morphogenesis. Dev Biol. 2002;248(1):68-81.

76. Chilosi M, Poletti V, Zamo A, Lestani M, Montagna L, Piccoli $P$, et al. Aberrant Wnt/beta-catenin pathway activation in idiopathic pulmonary fibrosis. Am J Pathol. 2003;162(5):1495-502.

77. Zeng X, Tamai K, Doble B, Li S, Huang H, Habas R, et al. A dualkinase mechanism for Wnt co-receptor phosphorylation and activation. Nature. 2005;438(7069):873-7.

78. Moreno-Bueno G, Hardisson D, Sánchez C, Sarrio D, Cassia R, García-Rostán G, et al. Abnormalities of the APC/ beta-catenin pathway in endometrial cancer. Oncogene. 2002;21(52):7981-90.

79. Gerstein AV, Almeida TA, Zhao G, Chess E, Shih leM, Buhler $K$, et al. APC/CTNNB1 (beta-catenin) pathway alterations in human prostate cancers. Genes Chromosomes Cancer. 2002;34(1):9-16. 
80. Howe LR, Brown AM. Wnt signaling and breast cancer. Cancer Biol Ther. 2004;3(1):36-41.

81. de La Coste $A$, Romagnolo $B$, Billuart $P$, Renard CA, Buendia $M A$, Soubrane $O$, et al. Somatic mutations of the beta-catenin gene are frequent in mouse and human hepatocellular carcinomas. Proc Natl Acad Sci USA. 1998;95(15):8847-51.

82. He B, You L, Uematsu K, Xu Z, Lee AY, Matsangou M, et al. A monoclonal antibody against Wnt-1 induces apoptosis in human cancer cells. Neoplasia. 2004;6(1):7-14.

83. You L, He B, Xu Z, Uematsu K, Mazieres J, Mikami I, et al. Inhibition of Wnt-2-mediated signaling induces programmed cell death in non-small-cell lung cancer cells. Oncogene. 2004;23(36):6170-4

84. Mazieres J, He B, You L, Xu Z, Lee AY, Mikami I, et al. Wnt inhibitory factor- 1 is silenced by promoter hypermethylation in human lung cancer. Cancer Res. 2004;64(14):4717-20.

85. Kim J, You L, Xu Z, Kuchenbecker K, Raz D, He B, et al. Wnt inhibitory factor inhibits lung cancer cell growth. J Thorac Cardiovasc Surg. 2007;133(3):733-7.

86. Yue W, Sun Q, Dacic S, Landreneau RJ, Siegfried JM, Yu J, et al. Downregulation of Dkk3 activates beta-catenin/TCF-4 signaling in lung cancer. Carcinogenesis. 2008;29(1):84-92.

87. You L, He B, Uematsu K, Xu Z, Mazieres J, Lee A, et al. Inhibition of Wnt-1 signaling induces apoptosis in beta-catenin-deficient mesothelioma cells. Cancer Res. 2004;64(10):3474-8.

88. Nakashima T, Liu D, Nakano J, Ishikawa S, Yokomise H, Ueno $M$, et al. Wnt1 overexpression associated with tumor proliferation and a poor prognosis in non-small cell lung cancer patients. Oncol Rep. 2008;19(1):203-9.

89. Ohira T, Gemmill RM, Ferguson K, Kusy S, Roche J, Brambilla E, et al. WNT7a induces E-cadherin in lung cancer cells. Proc Natl Acad Sci USA. 2003;100(18):10429-34.

90. Uematsu K, He B, You L, Xu Z, McCormick F, Jablons DM. Activation of the Wnt pathway in non small cell lung cancer: evidence of dishevelled overexpression. Oncogene. 2003;22(46):721821.

91. Uematsu K, Kanazawa S, You L, He B, Xu Z, Li K, et al. Wnt pathway activation in mesothelioma: evidence of Dishevelled overexpression and transcriptional activity of beta-catenin. Cancer Res. 2003;63(15):4547-51.

92. Wei $Q$, Zhao $Y$, Yang ZQ, Dong QZ, Dong XJ, Han Y, et al. Dishevelled family proteins are expressed in non-small cell lung cancer and function differentially on tumor progression. Lung Cancer. 2008;62(2):181-92.

93. Sunaga $N$, Kohno T, Kolligs FT, Fearon ER, Saito R, Yokota J. Constitutive activation of the Wnt signaling pathway by CTNNB1 (beta-catenin) mutations in a subset of human lung adenocarcinoma. Genes Chromosom Cancer. 2001;30(3):316-21.

94. Ohgaki $H$, Kros JM, Okamoto $Y$, Gaspert $A$, Huang $H$, Kurrer $\mathrm{MO}$. APC mutations are infrequent but present in human lung cancer. Cancer Lett. 2004;207(2):197-203.

95. Kase S, Sugio K, Yamazaki K, Okamoto T, Yano T, Sugimachi K. Expression of E-cadherin and beta-catenin in human non-small cell lung cancer and the clinical significance. Clin Cancer Res. 2000;6(12):4789-96

96. Suzuki M, Shigematsu H, Nakajima T, Kubo R, Motohashi S, Sekine $Y$, et al. Synchronous alterations of Wnt and epidermal growth factor receptor signaling pathways through aberrant methylation and mutation in non small cell lung cancer. Clin Cancer Res. 2007;13(20):6087-92.
97. Batra S, Shi Y, Kuchenbecker KM, He B, Reguart N, Mikami l, et al. Wnt inhibitory factor-1, a Wnt antagonist, is silenced by promoter hypermethylation in malignant pleural mesothelioma. Biochem Biophys Res Commun. 2006;342(4):1228-32.

98. Lee $A Y$, He B, You L, Dadfarmay S, Xu Z, Mazieres J, et al. Expression of the secreted frizzled-related protein gene family is downregulated in human mesothelioma. Oncogene. 2004;23(39):6672-6.

99. Tsuji T, Miyazaki $M$, Sakaguchi $M$, Inoue $Y$, Namba MA. A REIC gene shows down-regulation in human immortalized cells and human tumor-derived cell lines. Biochem Biophys Res Commun. 2000;268(1):20-4

100. Collins BJ, Kleeberger W, Ball DW. Notch in lung development and lung cancer. Semin Cancer Biol. 2004;14(5):357-64.

101. Aguayo AJ, Bray GM, Rasminsky M, Zwimpfer $T$, Carter $D$, Vidal-Sanz M. Synaptic connections made by axons regenerating in the central nervous system of adult mammals. J Exp Biol. 1990;153:199-224.

102. Bianchi $L$, Driscoll M. Heterologous expression of $C$. elegans ion channels in Xenopus oocytes. WormBook. 2006:1-16.

103. Shan L, Aster JC, Sklar J, Sunday ME. Notch-1 regulates pulmonary neuroendocrine cell differentiation in cell lines and in transgenic mice. Am J Physiol Lung Cell Mol Physiol. 2007;292(2):L500-9.

104. Greenblatt DY, Vaccaro AM, Jaskula-Sztul R, Ning $L$, Haymart $M$, Kunnimalaiyaan $M$, et al. Valproic acid activates notch-1 signaling and regulates the neuroendocrine phenotype in carcinoid cancer cells. Oncologist. 2007;12(8):942-51.

105. Sriuranpong $V$, Borges $M W$, Strock $C L$, Nakakura EK, Watkins DN, Blaumueller CM, et al. Notch signaling induces rapid degradation of achaete-scute homolog 1. Mol Cell Biol. 2002;22(9):3129-39.

106. Lee J, Platt KA, Censullo P, Ruiz i Altaba A. Gli1 is a target of Sonic hedgehog that induces ventral neural tube development. Development. 1997;124(13):2537-52.

107. Taipale J, Chen JK, Cooper MK, Wang B, Mann RK, Milenkovic $L$, et al. Effects of oncogenic mutations in Smoothened and Patched can be reversed by cyclopamine. Nature. 2000:406(6799):1005-9.

108. Ericson J, Morton S, Kawakami A, Roelink H, Jessell TM. Two critical periods of Sonic Hedgehog signaling required for the specification of motor neuron identity. Cell. 1996;87(4):66173.

109. Vestergaard J, Pedersen MW, Pedersen N, Ensinger C, Tümer Z, Tommerup N, et al. Hedgehog signaling in small-cell lung cancer: frequent in vivo but a rare event in vitro. Lung Cancer. 2006:52(3):281-90

110. Weaver $M$, Yingling JM, Dunn NR, Bellusci $S$, Hogan BL. Bmp signaling regulates proximal-distal differentiation of endoderm in mouse lung development. Development. 1999;126(18):4005-15

111. Pasca di Magliano M, Hebrok M. Hedgehog signalling in cancer formation and maintenance. Nat Rev Cancer. 2003;3(12):903-11

112. Barnes EA, Kong M, Ollendorff $V$, Donoghue DJ. Patched1 interacts with cyclin $\mathrm{B} 1$ to regulate cell cycle progression. EMBO J. 2001;20(9):2214-23.

113. Ohta M, Tateishi K, Kanai F, Watabe H, Kondo S, Guleng B, et al. p53-Independent negative regulation of p21/cyclin-de- 
pendent kinase-interacting protein 1 by the sonic hedgehogglioma-associated oncogene 1 pathway in gastric carcinoma cells. Cancer Res. 2005;65(23):10822-9.

114. Fan $\mathrm{H}$, Khavari PA. Sonic hedgehog opposes epithelial cell cycle arrest. J Cell Biol. 1999;147(1):71-6.

115. Yoshinori $A$, Tobiume $K$. The negative regulation of $p 53$ by hedgehog signaling. AACR. 2006. Abstract 1135-b.

116. Olsen CL, Hsu PP, Glienke J, Rubanyi GM, Brooks AR. Hedgehog-interacting protein is highly expressed in endothelial cells but down-regulated during angiogenesis and in several human tumors. BMC Cancer. 2004;4:43.

117. Kanda S, Mochizuki Y, Suematsu T, Miyata Y, Nomata K, Kanetake $\mathrm{H}$. Sonic hedgehog induces capillary morphogenesis by endothelial cells through phosphoinositide 3-kinase. J Biol Chem. 2003;278(10):8244-9.
118. Osada H, Tatematsu $Y$, Yatabe $Y$, Horio $Y$, Takahashi T. ASH1 gene is a specific therapeutic target for lung cancers with neuroendocrine features. Cancer Res. 2005;65(23):10680-5.

119. Linnoila RI, Zhao B, DeMayo JL, Nelkin BD, Baylin SB, DeMayo FJ, et al. Constitutive achaete-scute homologue-1 promotes airway dysplasia and lung neuroendocrine tumors in transgenic mice. Cancer Res. 2000;60(15):4005-9.

120. Salon C, Moro D, Lantuejoul S, Brichon Py P, Drabkin H, Brambilla $\mathrm{C}$, et al. E-cadherin-beta-catenin adhesion complex in neuroendocrine tumors of the lung: a suggested role upon local invasion and metastasis. Hum Pathol. 2004;35(9):1148-55.

121. Pelosi G, Scarpa A, Puppa G, Veronesi G, Spaggiari L, Pasini $F$ et al. Alteration of the E-cadherin/beta-catenin cell adhesion system is common in pulmonary neuroendocrine tumors and is an independent predictor of lymph node metastasis in atypical carcinoids. Cancer. 2005;103(6):1154-64. 